\title{
Legal Advice in Police Custody: From Europe to a Local Police Station
}

\author{
Anna Ogorodova \& Taru Spronken*
}

\begin{abstract}
In October 2013, the European Union adopted a Directive, which guarantees, inter alia, the right of access to a lawyer to suspects of criminal offences from the outset of police custody and during police interrogation. However, adoption of the relevant legislation is not sufficient to ensure that this right becomes effective in practice. A range of practical measures will have to be taken by the Member States' authorities and the legal profession to effectuate the implementation of the right to custodial legal advice. This article aims to identify the practical factors that may influence the implementation of the Directive, based on the findings of a recent normative and empirical study conducted by the authors. The research was carried out in four European jurisdictions (England and Wales, France, the Netherlands and Scotland), and it consisted of analysis of regulations, observations of daily practice in police stations, accompanying lawyers who provided custodial legal advice, and interviews with criminal justice practitioners. The article provides a range of recommendations on the practical measures to be undertaken by the EU Member States and national Bar associations aiming at improving the protection of suspects' rights in police custody in practice.
\end{abstract}

Keywords: legal advice, police interrogation, European Union, England and Wales, France

\section{Introduction}

Access to legal assistance in police custody has become a prominent issue in the national ${ }^{1}$ and European debates

Anna Ogorodova, LLM is PhD researcher at the University of Maastricht. Dr Taru Spronken is Professor of Criminal Law and Criminal Procedure at Maastricht University and Advocate General at the Supreme Court in the Netherlands. The authors of the article would like to thank Stephen Harsley, student at the European Law School programme of the Faculty of Law, Maastricht University, for his assistance in the editing process

1. For an overview of the national policy debates and legislative measures adopted to implement the Salduz v. Turkey judgment in the various Member States, see, for instance, C. Brants, 'The Reluctant Dutch Response to Salduz', 15 Edinburgh Law Review 298 (2011), D. Giannoulopoulos, "'North of the Border and across the Channel": Custodial Legal Assistance Reforms in Scotland and in France', 5 Criminal Law Review 369 (2013); E. Myjer, 'One Salduz a Year is Enough. 20 Associative Thoughts on Judge Rozakis, Judicial Activism and the Salduz Judgment', in D. Spielmann, M. Tsirli \& P. Voyatzis (eds.), The European Convention of Human Rights, a Living Instrument. Essays in Honour of Christos L. Rozakis (2011) 419. on criminal justice policy following a well-known decision of the European Court of Human Rights (hereinafter ECtHR) in Salduz v Turkey. ${ }^{2}$ In Salduz, the ECtHR held that, as a rule, every suspect detained by the police must benefit from access to a lawyer before the first interrogation, unless there exist compelling reasons to restrict this right. ${ }^{3}$ The legal standard established in Salduz has been further confirmed, and expanded upon, ${ }^{4}$ in more than one hundred judgments, commonly referred to as the Salduz jurisprudence. This has enabled the European Union to include strong provisions concerning the right of access to a lawyer in police custody in the newly adopted EU Directive on the right of access to a lawyer and to communicate with third persons (hereinafter the Directive). ${ }^{5}$ In particular, the Directive provides that the competent state authorities have a positive obligation to ensure effective access to a lawyer to all detained suspects without delay upon the deprivation of liberty. ${ }^{6}$ It also establishes the right of every suspected or accused person to have a lawyer present and to participate effectively when they are questioned by the criminal justice authorities, including the police. ${ }^{7}$

Adoption of the Directive is an important step towards safeguarding the right to custodial legal advice for suspects in the EU. However, as was demonstrated by previous research, ${ }^{8}$ it is unlikely to be sufficient to ensure effective protection of suspects' procedural rights. Besides respective legislation, Member States
4. For instance, the 'Salduz jurisprudence' made it clear that the right of access to legal advice applies during an interrogation of the suspect (see, most recently, Navone and others v. Monaco, ECHR (2014), Nos. $62880 / 11,62892 / 11$ and 62899/11) and developed the conditions of waiver of the right to legal assistance in police custody (see Section 2.2.2 below).

5. Directive 2013/48/EU of the European Parliament and of the Council of 22 October 2013 on the right of access to a lawyer in criminal proceedings and in the European Arrest Warrant proceedings, and on the right to have a third party informed upon deprivation of liberty and to communicate with third persons and authorities when deprived of liberty, OJ 2013, L 294/1.

6. See Arts. 3(1) and (2) and Recital 28 of the Directive on the right of access to a lawyer, above n. 5 .

7. Art. 3(3)b and Recital 25, ibid.

8. E. Cape, Z. Namoradze, R. Smith \& T. Spronken, Effective Criminal Defence in Europe (2010), E. Cape and Z. Namoradze, Effective Criminal Defence in Eastern Europe (2012), S. Schumann, K. Bruckmuller \& R. Soyer (eds.), Pre-Trial Emergency Defence (2012). 
should have procedures and institutional mechanisms 9 in place to effectuate the various provisions of the EU laws in practice. Furthermore, appropriate professional cultures are needed to facilitate the implementation of suspects' procedural rights. ${ }^{10}$ This article presents an analysis of some of the abovementioned practical factors - namely, the existing procedures, institutional mechanisms and professional cultures - that may influence the implementation of the Directive. The analysis is largely based on the findings of an empirical study carried out by us (together with others), which were recently published in J. Blackstock et al.,Inside police custody: an empirical account of suspects' rights in four jurisdictions (hereinafter Inside Police Custody). ${ }^{11}$ In this study, we undertook empirical research, observing daily practice in police stations and accompanying lawyers who provided custodial legal advice in four jurisdictions within the EU - England and Wales, France, the Netherlands and Scotland - in the period of 2011-2013. ${ }^{12}$ We chose France, the Netherlands and Scotland, because they had undergone recent changes in their systems, allowing access to lawyers before the first police interrogation following the Salduz judgment of the ECtHR in 2008. England and Wales was included as a jurisdiction that could offer examples of good practice, because there custodial legal advice has been provided since the entry into force of the Police and Criminal Evidence Act 1984 (hereinafter PACE) in 1986. Based on the outcomes of this research we were able to provide suggestions about how to improve the protection of suspects' rights in police custody in practice.

This article consists of three parts. In Section 1, a brief overview is given of the European standards on the right to legal assistance in police custody, and in particular its following elements: conditions for waiver of the right, the right of timely access to a lawyer and the right of access to a lawyer of one's choice, the right to have a lawyer present at suspect interrogations and the right to effective assistance of a lawyer during suspect interrogations. In Section 2, the article describes the findings of the Inside Police Custody related to the abovementioned elements of the right to custodial legal advice. The objective is to identify the possible (trans-jurisdictional) factors, other than the existence of relevant legislation, which may influence the implementation of the Directive. In conclusion, we formulate a number of recommendations on the implementation of the Directive.

9. Such as, for instance, procedures to verify the validity of waiver of procedural rights by suspects and accused persons, or organised services of professional interpreters, available to provide interpretation at short notice (as an example of an institutional mechanism necessary to effectuate the right of suspects and accused persons to interpretation and translation in criminal proceedings).

10. For example, an active professional culture of criminal defence. See Cape et al. (2010), above n. 8, at 574.

11. J. Blackstock, E. Cape, J. Hodgson, A. Ogorodova \& T. Spronken, Inside Police Custody: An Empirical Account of Suspects' Rights in Four Jurisdictions (2014). This 2-year project was a collaborative effort of the Maastricht University, University of the West of England, JUSTICE and Warwick University and it was funded by the European Commission.

12. For more details concerning the research methodology of the study, see section 4 below.

\section{The European Standards on the Right of Access to a Lawyer in Police Custody}

For a long time, the Council of Europe and the European Court of Human Rights had been the only institutions to generate Europe-wide standards on the suspects' procedural rights in criminal proceedings. ${ }^{13}$ Recently, however, the European Union emerged as a significant player in this area. In 2009, the Roadmap on the suspects' procedural rights was adopted, a legislative and policy programme aimed to strengthen the procedural rights of suspects and accused in criminal proceedings across the EU. ${ }^{14}$ In 2012-2013, three Directives on various suspects' procedural rights were adopted. ${ }^{15}$ Other instruments are envisaged, namely, on the right to legal aid in criminal proceedings, on the rights of vulnerable suspects, the presumption of innocence and pre-trial detention. ${ }^{16}$

\subsection{Relationship between the ECHR and the Directive}

One of the purposes of the Directive is to codify and reinforce the provisions of the ECHR and ECtHR case law. ${ }^{17}$ Thus, for the most part, the Directive repeats the respective standards derived from the ECtHR case law.

13. These standards were mostly derived from Art. 6 of the ECHR encompassing the right to a fair trial of everyone charged with a criminal offence.

14. Resolution of the Council of 30 November 2009 on a Roadmap with the view to fostering protection of suspected and accused persons in criminal proceedings (2009), OJ C 295/1.

15. Directive 2010/64/EU of the European Parliament and of the Council of 20 October 2010 on the right to interpretation and translation in criminal proceedings (2010), OJ L 280; Directive 2012/13/EU of the European and the Directive on the right of access to a lawyer, above n. 5 .

16. Proposal for a Commission Recommendation on procedural safeguards for vulnerable persons suspected or accused in criminal proceedings C 8178/2 (2013), unpublished, available at: <http://ec.europa.eu/ justice/criminal/files/c_2013_8178_en.pdf >; Proposal for a Directive of the European Parliament and the Council on procedural safeguards for children suspected or accused in criminal proceedings $\operatorname{COM}(2013) 822 / 2$, unpublished, available at: <http://ec.europa.eu/ justice/criminal/files/com_2013_822_en.pdf >; Proposal for a Directive of the European Parliament and the Council on provisional legal aid for suspects or accused persons deprived of liberty and legal aid in European arrest warrant proceedings $\operatorname{COM}(2013) 824$ final, unpublished, available at: <http://eur-lex.europa.eu/LexUriServ/LexUriServ.do?uri=COM: 2013:0824:FIN:EN:PDF>; Proposal for a Commission Recommendation on the right to legal aid for suspects or accused persons in criminal proceedings C 8179/2 (2013), unpublished, available at: <http://ec.europa. eu/justice/criminal/files/c_2013_8179_en.pdf>; Proposal for a Directive of the European Parliament and the Council on the strengthening of certain aspects of the presumption of innocence and of the right to be present at trial in criminal proceedings $\operatorname{COM}(2013) 821 / 2$, unpublished, available at: <http://ec.europa.eu/justice/criminal/files/com_2013_821_ en.pdf> (last visited 18 December 2013).

17. For a number of reasons described elsewhere, the ECHR enforcement regime is believed to be less capable that of the EU to ensure compliance of the national authorities with their obligations to safeguard suspects' procedural rights. Thus, additional legislative action from the EU was deemed necessary to ensure that the standards related to the procedural rights of suspects found in the ECtHR case law were consistently implemented by the EU Member States. See Cape et al. (2010), above n. 8 at 13 . 
At times, however, it expands the ECtHR standards by providing detail concerning the mechanisms of their implementation. For illustration, the provisions of the Directive on verification of the waiver of the right to legal advice ${ }^{18}$ build up upon the ECtHR case law concerning waiver of procedural rights. ${ }^{19}$ On the other hand, the Directive does not cover certain issues addressed in ECtHR case law, or the standards found in ECtHR case law are more detailed than those of the Directive. One example is the right of access to a lawyer of one's choice, which is not mentioned in the Directive. Where the standards found in the ECtHR case law are more developed than those of the Directive, they must be taken into account when interpreting the respective Directive provisions. That is, inter alia, because Recital 53 to the Directive states that the Member States should ensure that the provisions of this Directive, where they correspond to rights guaranteed by the ECHR, are implemented consistently with those of the ECHR and as developed by case-law of the European Court of Human Rights.' This effectively means, in our view, that the Member States must incorporate in their implementing legislation not only the provisions of the Directive but also the ECHR norms and ECtHR case law relevant to the right of access to a lawyer in criminal proceedings. Furthermore, the competent EU institutions will arguably need to take into

account these standards and norms when assessing compliance of the Member States with the Directive as provided for in Article $16 .^{20}$

Moreover, the respective ECHR standards may in the future be incorporated into the Directive by the Court of Justice of the European Union (CJEU), which is vested with the authority to provide interpretations of EU law provisions, binding on the Member States. ${ }^{21}$ The need for the CJEU to take into account the ECHR standards when interpreting provisions on the fundamental rights (including the right to a fair trial) ${ }^{22}$ is explicitly provided for in the EU Charter of Fundamental Rights. ${ }^{23}$ In the recent years, the number of references made by the CJEU to the ECHR and ECtHR case law has increased. ${ }^{24}$ Furthermore, after the EU accession to the European Convention of Human Rights mandated

18. Directive on the right of access to a lawyer, above n. 5, Art. 9.

19. See section 3.1 below

20. Art. 16 of the Directive on the right of access to a lawyer provides that 'the European Commission shall, by 28 November 2019, submit a report to the European Parliament and to the Council, assessing the extent to which the Member States have taken the necessary measures in order to comply with this Directive.'

21. Art. 267 of the Treaty on the Functioning of the European Union.

22. Art. 47 of the EU Charter of Fundamental Rights provides for a right for a fair trial and effective remedy.

23. Art. 53(2) of the EU Charter of Fundamental Rights provides that 'The CJEU must give provisions of the Charter modeled on provisions of the ECHR similar meaning'. The Charter of Fundamental Rights became legally binding after the adoption of the Lisbon Treaty in 2009.

24. See A.S. Arnaiz and A.T. Perez, 'Main trends in the recent case law of the EU Court of Justice and the European Court of Human Rights in the field of fundamental rights', Study Prepared for the European Parliament's Civil Liberties, Justice and Home Affairs Committee (2012), at 13. by the Treaty of the European Union, ${ }^{25}$ CJEU will apply the ECHR standards directly as EU law. For all the reasons mentioned above, it is very likely that the CJEU will rely on the ECHR standards when interpreting the provisions of the Directive on the right of access to a lawyer.

\section{The Elements of the Right of Access to a Lawyer}

The right to effective access to legal assistance encompasses many elements. ${ }^{26}$ In this article, however, we focus on five particular aspects of the right to legal advice, which have figured most prominently in our empirical study (focused on the stage of the first police interrogation). ${ }^{27}$ Four of them are mentioned in the Directive, namely, the conditions of waiver of the right, ${ }^{28}$ the right of timely access to a lawyer, ${ }^{29}$ the right to have a lawyer present at suspect interrogations, ${ }^{30}$ and the right to effective participation of a lawyer during interrogations of a suspect. ${ }^{31}$ The fifth aspect of the right to effective legal advice, which we focus on is in this article, namely, the right to a lawyer of one's choice, is not explicitly provided for in the Directive, ${ }^{32}$ but it is contained in the ECHR. ${ }^{33}$ Nonetheless, it is relevant for our analysis, because as it is argued in Section 2.1 above, it may be 'read into' the Directive in the implementation process or by means of interpretative judgments of the Court of Justice of the European Union.

\subsection{Waiver of the Right to Legal Advice}

The conditions for a valid waiver, including the respective informational duty of the authorities, are listed in Article 9 of the Directive. Namely, the waiver is conditional upon the fact that the authorities have provided suspects with clear and sufficient information in simple and understandable language about the content of the right to legal assistance and the consequences of waiving it. ${ }^{34}$ Furthermore, the authorities must make sure that the waiver was voluntary and unequivocal. ${ }^{35}$ In our view, the duty to inform about the consequences of waiving the right to legal advice also implies the obligation to inform the suspect about the offence(s) he is suspected of, which is already provided for in the Directive on the right to information in criminal proceedings. ${ }^{36}$

25. Art. 6(2) of the Treaty of the European Union.

26. E.g. the right to have confidential meetings with the lawyer, or the right to have a lawyer present at the investigative actions undertaken by the police, if provided by national law. See Directive on the right of access to a lawyer, above n. 5, Art. 3(2)(b) and (4).

27. See Blackstock et al., above at 11, Chapters 6, 7 and 8 .

28. Directive on the right of access to a lawyer, above n. 5, Art. 9.

29. Ibid., Art. 3(2).

30. Ibid., Art. 3(3)(b)

31. Ibid.

32. See section 2.1 above.

33. Art. 6(3)(c) ECHR

34. Directive on the right of access to a lawyer, above n. 5, Art. 9(1)(a).

35. Ibid., Art. 9(1)(b)

36. Ibid., Art. 6. 
This information appears necessary, inter alia, so that the suspect could decide whether the seriousness of the charge warrants the presence of a lawyer. ${ }^{37}$

The waiver and the circumstances of the waiver must be recorded. ${ }^{38}$ By definition, a waiver cannot be considered voluntary where the police sought to discourage the suspect from exercising the right. This may include providing clearly inaccurate information, whether deliberately or not (e.g. telling the suspect that he will have to pay for a lawyer, whilst legal advice is free of charge), or misleading suspects in more subtle ways, e.g. telling them that if they ask for a lawyer it will take longer, whilst in reality the length of detention does not always depend on the suspect's decision to see a lawyer. ${ }^{39}$ The conditions for a waiver must be met particularly strictly where vulnerable suspects are concerned. Where a vulnerable suspect is involved, the authorities should have taken all reasonable steps to 'ensure that a vulnerable suspect is fully aware of his rights of defence and can appreciate, as far as possible, the consequences of waiving them. ${ }^{40}$ Furthermore, where vulnerable suspects are concerned, waiver of the right to legal assistance during police custody must be explicit. ${ }^{41}$ An implicit waiver made by a vulnerable suspect, for example by signing the information form about the rights and agreeing to respond to interrogation, will not be valid under ECtHR case law. ${ }^{42}$ The proposed instruments on the rights of vulnerable suspects in criminal proceedings in the EU recently made public by the European Commission $^{43}$ go even further by suggesting that certain groups of vulnerable suspects should never be allowed to waive their right to legal advice. Specifically, according to a proposed Directive on procedural safeguards for children, legal assistance in criminal proceedings for children should be mandatory, except for very minor cases. ${ }^{44}$ Furthermore, the draft recommendation on procedural safeguards for vulnerable persons suggests that criminal suspects who cannot follow and understand the proceedings should also be unable to waive their right to legal assistance. ${ }^{45}$

\subsection{Timely Access to a Lawyer during Police Custody}

According to the Directive, suspects or accused persons must be provided with access to a lawyer without undue

Empirical studies have systematically shown that the seriousness of the offence was an important factor affecting the suspects' decision to request legal assistance. See e.g. L. Skinns, " "Let's get it over with": early findings on the factors affecting detainees' access to custodial legal advice', 58 Policing \& Society, at 64-5 (2009), and other studies listed under n. 35 in P. Pleasance, V. Kemp \& N. Balmer, 'The Justice Lottery? Police Station Legal Advice 25 Years on from PACE', 3 Criminal Law Review (2011).

38. Directive on the right of access to a lawyer, above n. 5, Art. 6(2).

39. For discussion of the related practice, see section 4.1.2

40. Panovits v. Turkey, ECHR (2008), No. 4268/04, 68.

41. Ibid.

42. Plonka v. Poland, ECHR (2009), No. 20310/02, 37.

43. Above n. 16.

44. Ibid., Art. 6.

45. Above n. 16, para. 11

delay after the moment of deprivation of liberty. ${ }^{46}$ Thus, the Directive makes it clear that the right applies from the outset of police custody, and not only if and when a detained suspect is interrogated by the police. This resolves any uncertainties of interpretation of the existing ECtHR case law on the matter. ${ }^{47}$

The Directive furthermore provides that Member States must ensure timely access to a lawyer, ${ }^{48}$ and that in any case the suspect should have the possibility to meet in private with his lawyer before any questioning. ${ }^{49}$ Besides, it requires that Member States 'shall make the necessary arrangements to ensure that suspects or accused persons who are deprived of liberty shall be in a position to practically and effectively exercise their right of access to a lawyer.' ${ }^{50}$ It follows from the Directive and the relevant ECtHR case law that the police are not entitled to interrogate a suspect who has not had a prior consultation with the lawyer, unless he has validly waived such right before the interrogation. ${ }^{51}$ The only situations where a derogation is possible are mentioned in the Directive, and they include circumstances where there is a pressing need to interrogate a suspect, for instance, to prevent an imminent risk to life or destruction of evidence. ${ }^{52}$

\subsection{The Right to Choose a Lawyer}

Article 6(c) of the ECHR provides a right to all criminal suspects to be defended 'by himself or the lawyer of his choice'. It is unclear however whether the right belongs equally to suspects paying privately for the services of a lawyer, as well as to those suspects whose lawyer is paid for by the state. ${ }^{53}$ The ECtHR has held that the right of choice of a lawyer is not absolute where a lawyer is paid for by the state. ${ }^{54}$ Although the authorities must take account of the wishes of the suspect to appoint a certain lawyer - which underlines the importance of a relationship of trust between a lawyer and a suspect - where it concerns legally aided suspects, this choice may be overridden 'where there are sufficient and relevant reasons to believe that the interests of justice so require'. ${ }^{55}$ The proposed recommendation on the right to legal aid provides that, where suspects make use of a state-appointed lawyer, 'the preference and wishes of the suspects or accused persons and requested persons should as far as possible be taken into account by the national legal aid systems in the choice of the legal aid lawyer.' 56

46.

47. Cape and Namoradze (2012), above n. 8, at 50-2; Salduz v. Turkey, above n. 2; Zaichenko v. Russia, ECHR (2010), No. 39660/02; Dayanan v. Turkey, ECHR (2009), No. 7377/03.

48. Directive on the right of access to a lawyer, above n. 5, Art. 3(2)(c).

49. Ibid., Art. 3(3)(a)

50. Ibid., Art. 3(2)(b)

51. Ibid., Art. 3(3)(a) and Art. 8, Recitals 30-32; Pischchalnikov v. Russia, ECHR (2009), No. 7025/04, 79.

52. Directive on the right of access to a lawyer, above n. 5, Art. 3(6), Recitals 31 and 32 .

53. Cape et al. (2010), above n. 8.

54. Croissant v. Germany, ECHR (1992), No. 13611/88, 29; Lagerblom v. Sweden (2003), No. 26891/95, 54

55. Ibid.

56. Above n. 16. 
The requirement to respect the choice of a lawyer is stricter in case of suspects who pay for lawyer's services privately; however, the ECtHR has ruled that the right may also be limited 'in exceptional circumstances where it is necessary to override this right in the interests of justice or where this is associated with justifiable and significant obstacles. ${ }^{57}$ It is unclear what these 'exceptional circumstances' may be, but arguably the authorities' wish to proceed with the interrogation despite the temporary unavailability of a privately paid lawyer does not constitute such circumstances. ${ }^{58}$

\subsubsection{The Right to Have a Lawyer Present at Interrogations and the Lamyer's Role at Interrogations}

In line with ECtHR case law, ${ }^{59}$ the Directive provides that all suspects should have the right to have a lawyer present during their interrogations by police. ${ }^{60}$ The Directive furthermore provides that a lawyer should be able to 'participate effectively' in the interrogation, but that such participation shall be in accordance with the procedures under national law. ${ }^{61}$ However, such procedures must not 'prejudice the effective exercise and essence of the right' ${ }^{62}$ This is further explained in Recital 25, which states that 'the lawyer may, inter alia, in accordance with such rules, ask questions, request clarification and make statements.'

These provisions, in our view, should be interpreted in line with ECtHR case law on the matter. Given that according to the ECtHR the primary rationale for the right to legal assistance during interrogations is to safeguard the suspect's right to remain silent, ${ }^{63}$ the lawyer must as a minimum be able to intervene to protect his client's right to silence and to prevent unlawful or unfair behaviour of the police depriving the client of this right. Furthermore, a lawyer should arguably be able to exercise his 'core' function of providing confidential advice to his client ${ }^{64}$ in the course of interrogation, and subsequently to seek to stop the interrogation for this purpose. Besides this, in line with another rationale of the right of access to a lawyer in police custody - safeguarding the equality of arms, a lawyer should be able to point to the elements of the case that are favourable to his client, provide him with moral support and ensure that the record of the interrogation is accurate. ${ }^{65}$

57. Dvorski v. Croatia, ECHR (2013), No. 25703/11, 94

58. See, mutatis mutandis, Pavlenko v. Russia, ECHR (2010), No. $42371 / 02,114$. In this case, a violation of Art. 6(3)(c) was found, because the authorities failed to react to applicant's complaints about ineffectiveness of his legally-aided counsel and requests to invite a privately-paid lawyer, because they wished to advance with the investigation.

59. Salduz v. Turkey, above n. 2 and subsequent judgments.

60. Directive on the right of access to a lawyer, above n. 5, Art. 1(3)(b).

61. Ibid.

62. Ibid.

63. Salduz v. Turkey, above n. 2,54

64. Directive on the right of access to a lawyer, above n. 5, Arts. 3(3)(a) and 4 .

65. See e.g. Dayanan v. Turkey, above n. 47. Also see the articulation of the lawyer's role during interrogation in Blackstock et al., above n. 11, at 394-5.

\section{The Right to Legal Assistance in Police Custody in the Four Jurisdictions}

This section largely relies on the findings reported in Inside Police Custody, as well as data not included in the final publication. ${ }^{66}$ The study was a combination of legal (normative) analysis and empirical research. Data were collected on eleven sites ${ }^{67}$ across four jurisdictions. Observations were carried out at police stations, as well as at criminal law firms, or with individual lawyers participating in police station legal advice duty schemes. ${ }^{68}$ Where the necessary permissions were obtained, researchers spent at least 4 months observing at police stations, and 2 months observing with the lawyers in each jurisdiction. ${ }^{69}$ However, in some jurisdictions, we were unable to obtain permissions to carry out (parts of) the observations. ${ }^{70}$ This explains the differences in the time spent by researchers in carrying out observations in different jurisdictions, as well as the asymmetry in the reported findings. In addition to observations, researchers conducted over eighty semi-structured qualitative interviews with police officers and legal practitioners. The methodology of the study is described in detail in Inside Police Custody. ${ }^{71}$

\subsection{Waiver of the Right to a Lawyer and Informing Suspects about the Right}

The issue of waiver of a procedural right is intrinsically linked with the authorities' duty to inform suspects about this right in an effective way, including the obligation to inform them about the consequences of waiving the right. Thus, the paragraphs below will cover the national regulations on waiver of the right to legal advice, as well as on the procedures for informing suspects about this right, and their application in practice in the studied jurisdictions.

66. Fieldnotes are referenced as follows: e.g. NethSite1Pol4 stands for the jurisdiction (Neth), site number (Site1), observations with the police (Pol) on the fourth day (4). Interviews are referenced as follows: e.g. iEngSite2Law4 stands for the jurisdiction (England and Wales), site number (Site2), fourth interview with a lawyer (Law).

67. For the purposes of our study, a 'site' corresponded to a judicial district. The choice of the sites depended largely on our ability to obtain permissions to carry out observations in the given district.

68. The arrangements for observations with lawyers differed per jurisdictions. In France and in the Netherlands, researchers were attached to individual lawyers who attended police stations under the framework of police station legal advice duty schemes (see section 4.2 .2 below). In England and Wales, researchers were attached to criminal law firms.

69. See the overview of the data collection periods in Blackstock et al., above $n .11$ at 561 .

70. For instance, in Scotland researchers had limited opportunities to observe with law firms and they had no access to suspect interrogations. In France, we were unable to obtain permissions to conduct observations at police stations, as well as (on one of the sites) with lawyers attending police stations, despite lengthy negotiations. See Blackstock et al., above n. 11 at 56-7.

71. See Chapter 2 in Blackstock et al., above n. 11 at 37-69. 


\subsubsection{Regulations on Waiver of the Right to a Lamyer in Police Custody}

In all studied jurisdictions, suspects of criminal offences can waive their right to legal advice in police custody. ${ }^{72}$ None of these jurisdictions provides for mandatory legal advice, where certain groups of suspects cannot waive their right to a lawyer. The Netherlands is the only country that has a system which resembles mandatory legal assistance. Namely, in the Netherlands the police must invite a lawyer to consult with all suspects who are arrested in respect of most serious offences and with minors younger than 16 years, before commencing the first interrogation. ${ }^{73}$ However, after consulting with the lawyer, these suspects may waive their right to (further) legal assistance.

The regulations on informing suspects about the right to legal advice vary greatly in the four jurisdictions. ${ }^{74}$ In France and in the Netherlands, there is a general duty of police officers to inform suspects about the right to custodial legal advice, but there are no regulations as to the form and manner in which this information should be provided. ${ }^{75}$ In England and Wales, Code of Practice C of PACE regulates the duty to inform about the right in more detail, i.e. that it must be done in a clear manner, orally and in writing, that suspects should be told that they may see a lawyer at any stage of police custody, etc. ${ }^{76}$

The most elaborate procedure of informing suspects about their right to legal advice exists in Scotland. This procedure $^{77}$ was introduced by the national police authority to implement the respective law ${ }^{78}$ which was adopted following the Cadder case. ${ }^{79}$ The so-called Solicitor Access Record Form (hereinafter SARF) was developed to ensure that suspects are informed about their right to a lawyer in a uniform manner. ${ }^{80}$ The form must be read verbatim, and it includes a number of statements and questions concerning whether or not the suspect understands the right to legal advice and wishes to exercise it. The phrasing of the form itself is extremely unfortunate, as it is (four pages) long and repetitive and uses complex language. ${ }^{81}$ Despite this, the same form is used in respect of children and vulnerable suspects.

Only in England and Wales is it required by law that, in addition to oral notification about the right to a lawyer, suspects were provided with written information about

72. Ibid. at $81,97,114,133-34$

73. Aanwijzing rechtsbijstand politieverhoor 15 februari 2010, Stcrt. 2010 4003.

74. Blackstock et al., above n. 11 at 214-16.

75. Ibid. at 91, 108

76. PACE Code of Practice C, paras. 3.1-3.2.

77. See Association of Chief Police Officers in Scotland (ACPOS) Custody Manual of Guidance (2010).

78. See S 15 (A) Criminal Procedure (Scotland) Act 1995

79. In Cadder, the UK Supreme Court found that the use at trial of evidence obtained during police interrogation without prior access to a lawyer will irretrievably violate the right to a fair trial. Cadder v. HM Advocate [2010] UKSC 43.

80. Blackstock et al., above n. 11 at 126

81. Ibid. at 230-34. the right to a lawyer. ${ }^{82}$ In other jurisdictions, standardised written information is available, but there is no obligation of the authorities to provide it to suspects.

All jurisdictions have some general legal norms in place concerning the conditions for waiver of the right to legal advice. ${ }^{83}$ These norms, contained in regulations or developed by case law, usually require that the waiver should be explicit and unequivocal and that it should be recorded. However, in none of the four jurisdictions with the (partial) exception of England and Wales, is there a procedure in place to verify whether the waiver is voluntary and informed. ${ }^{84}$ In England and Wales, PACE Code $\mathrm{C}$ provides that if the suspect refuses to see a solicitor, an officer must ask the person for the reasons for such a decision. ${ }^{85}$ However, this procedure does not, in our view, amount to a proper verification of the waiver. That is because an officer is not obliged to inform the suspect about the consequences of using or not using the right and to ascertain that the suspect understood them; nor is he expected to react in any way, if it appears that the suspect did not understand the meaning of the right or the implications of waiving it. ${ }^{86}$

The treatment of vulnerable suspects in relation to the waiver of the right to a lawyer varies considerably in the four jurisdictions. In none of these jurisdictions are there any special procedures aimed at informing vulnerable suspects about their right in a way that is understandable to them, i.e. depending on the nature of their vulnerability and their age. ${ }^{87}$ Only in the Netherlands is there a provision, according to which certain categories of suspects (e.g. children under the age of 16) may waive their right to legal advice only after a prior consultation with a lawyer. ${ }^{88}$ Another safeguard meant to ensure that vulnerable suspects understand their rights is the institution of an 'appropriate adult' that exists in England and Wales and in Scotland (but

82. Ibid. at 216.

83. Ibid. at $81,97,114,133-34$.

84. In Scotland, the ACPOS Manual of Guidelines on Solicitor Access provides that, as a pre-requisite of the valid waiver, suspects should be asked whether they have understood their rights and whether they wish to exercise them. This procedure, however, does not include an element of verification of whether the suspects understood their rights and the implications of waiver. See ACPOS Manual of Guidelines on Solicitor Access (2011) at 10, 22.

85. However, if the suspect insists on the decision to waive the right, the officer must refrain from asking the person the reasons for the decision further. PACE Code of Practice C, para. 6.5, Note for Guidance 6K.

86. See Section 3.1 above

87. Although in some jurisdictions, for instance in Scotland and in the Netherlands, there is case law stating that in respect of (some) vulnerable suspects, waiver of the right to legal advice should not be accepted where they were informed about their right to legal advice in a way usually practised in the given jurisdiction. See e.g. McGowanv. B. [2011] UKSC 54, cited in Blackstock et al., above n. 11 at p. 134; Rechtbank Arhnem (2010), LJN BN515; Rechtbank Amsterdam (2012), LJN BY8839.

88. See above. In Scotland, The ACPOS Manual of Guidance for Solicitor Access provides that for children and those aged 16 and 17 there is a presumption that they should have access to advice from a solicitor and every effort should be made to obtain those services. See Blackstock et al., above n. 11 at 134 . However, this provision is different in nature from a duty to engage a lawyer to verify the validity of the waiver of the right to legal advice. 
not in France and the Netherlands). ${ }^{89}$ An appropriate adult is a parent, another relative or a social worker, whose role is, inter alia, to help vulnerable suspects to understand their rights, and to help them decide whether they wish to exercise them or not. ${ }^{90}$ An appropriate adult may consider inviting a lawyer to a vulnerable suspect if he believes it in the suspect's best interest, even if the latter indicates that he does not want legal advice, but the suspect cannot be forced to see the lawyer if he refuses to do so. ${ }^{91}$

\subsubsection{Waiver of the Right to Legal Assistance and} Informing Suspects about the Right in Practice

The estimated rates of waiving of the right to legal advice in police custody in the studied jurisdictions were between 50 and $75 \% .{ }^{92}$ These figures should be treated with caution, ${ }^{93}$ but it is undisputed that in all four jurisdictions a large number of suspects waive their right to legal assistance. ${ }^{94}$

In none of the four jurisdictions did we observe suspects being threatened or tricked by the police into waiving their right to a lawyer. It may be, however, that the inherent limitations on the design of our study prevented us from picking up appropriately on the instances of serious police misconduct. ${ }^{95}$ At the same time, our research has shown that the operation of the provisions aimed at informing suspects about the right and to verify the waiver was problematic in some ways in all studied countries.

There was a striking difference in the four jurisdictions in the way that the provision of information on rights by the police to suspects was organised. England and Wales and Scotland have a highly regulated structure, with very strict recording procedures. The 'booking in' process during which suspects are informed of their rights is recorded on video. Furthermore, the officers dealing with the booking in process, the so-called 'custody officers', are senior-rank officers, whose only role is to implement police custody procedures and who are not in any way involved in case investigations.

89. In the Netherlands, juvenile suspects may be assisted by a 'trusted person' during interrogation (as an alternative to a lawyer). However, the role of a 'trusted person' is narrower than that of an 'appropriate adult'. See Blackstock et al., above n. 11 at 244.

90. See Blackstock et al., above n. 11 at 245.

91. PACE Code of Practice C, para. 6.5A

92. Blackstock et al., above n. 11 at $81,97,114,133$

93. There were no reliable statistical data on the rates of waiver of custodial legal advice collected on the national level in any of the four jurisdictions. Most of the existing empirical studies of the uptake rates of legal advice were conducted in England and Wales. However, the most recent large-scale study was undertaken in this jurisdiction about 20 years ago (namely, in 1997). See Pleasance, Kemp \& Balmer, above n. 36 at 5-6. In the Netherlands, there was no available statistical data at all; in France and in Scotland the only data available were the statistics cited in government reports, the reliability of which could not be verified. See Blackstock et al., above n. 11 at 97, 114 and 134.

94. During our observations at the Dutch police stations, for instance, 45 out of 94 suspects waived their right to legal assistance. See Blackstock et al., above n. 11 at 278

95. The relatively short observation periods spent on the research sites may have been insufficient to overcome any 'observer effect' caused by the researchers' presence. Besides, our study did not include interviews with criminal suspects, which could have yielded different findings.
By contrast, in France ${ }^{96}$ and in the Netherlands, there were far less detailed regulations or instructions as well as fewer provisions to scrutinise or verify compliance. As a consequence in the Netherlands, the manner of informing suspects about the right depended greatly on the officer's own approach and style. ${ }^{97}$ For instance, we observed some officers simply telling suspects that they have the right to a lawyer and asking them whether they wanted one; ${ }^{9}$ yet the majority also mentioned that a lawyer was free of charge and/or that a suspect could choose between an 'own' lawyer and the one contacted by the police. ${ }^{99}$ Still, some officers added to this that exercising the right to a lawyer will cause delay, ${ }^{100}$ whilst others encouraged suspects to take up legal advice by asking the question twice or telling them that they may change their mind later. ${ }^{101}$

In the Netherlands, the officers informing suspects about the suspected offence and about their rights (socalled 'assistant prosecutors') are senior police officers, who are often involved in the investigation (e.g. in a supervisory capacity). ${ }^{102}$ They may therefore have interests, which are in a direct conflict with the interest to guarantee the effective exercise of suspects' rights. One obvious example is the interest to complete the investigation as quickly as possible, which, as some officers may believe, ${ }^{103}$ could be compromised when the suspect uses his right to legal assistance. A minority of assistant prosecutors in our study have given priority to the interests of the investigation when informing suspects about their right to legal assistance. ${ }^{104}$ For instance, one older assistant prosecutor observed in NethSitel persuaded a suspect, inter alia, to waive her right to legal assistance to aid his younger colleagues to deal with the interrogation in a speedier manner. ${ }^{105}$ Some assistant prosecutors were also observed to 'nudge' suspects into waiving their right to a lawyer, when there was a possibility to 'process' the case by means of an accelerated case

96. In France, we were unable to get a permission to observe at police stations, and thus we did not have a possibility to observe how suspects were informed about their right to legal advice by the police, but we could accompany lawyers to the police stations and interview them about how suspects were informed

97. Blackstock et al., above n. 11 at 217-26.

98. NethSite1Pol1; NethSite1Pol7; NethSite1Pol10.

99. See an example in Blackstock et al., above at 11 at 225; NethSite1Pol2; NethSite1Pol6; NethSite1Pol7.

100. NethSite1Pol1; NethSite1Pol6; NethSite1Pol7; NethSite1Pol25. For the discussion of this practice, see below.

101. See an example in Blackstock et al., above n. 11 at p. 229; NethSite1Pol7; NethSite1Pol13; NethSite1Pol30.

102. For instance, they may hold senior positions in the investigation department.

103. See the text belonging to $n$. 114 below

104. We have also observed assistant prosecutors who made an extra effort to ensure that suspects may benefit from the right to legal assistance. For relevant examples, see Blackstock et al., above n. 11 at 229 .

105. This was a less serious offence (social benefits' fraud), and the evidence against the suspect was overwhelming. The suspect appeared highly suggestible. The assistant prosecutor used the conversation aimed at informing the suspect about the offence and her rights to persuade the suspect to confess by confronting her with the evidence, as well as to waive her right of access to a lawyer. See NethSite1Pol1. Blackstock et al., above n. 11 at 279 . 
disposal. ${ }^{106}$ This is to be contrasted with the situation in England and Wales where the officers who deliver procedural rights to suspects are not vested with any investigation-related tasks. Besides, their duties to inform suspects about their rights, and the manner in which this should be done, are regulated in detail by the respective legislation, which is not the case in the Netherlands. ${ }^{107}$

In Scotland, as mentioned above, the SARF form prescribes that officers use exactly the same wording to inform all suspects about their right to custodial legal advice. This form, however, was difficult to use, as the sequence of the questions was illogical, they were repetitive (e.g. asking whether a suspect wants legal assistance in three different ways), the form itself was long-winded and it used the language that most suspects were unlikely to understand, such as 'have intimation sent to a solicitor'. ${ }^{108}$ In England and Wales, officers were guided by the so-called 'record of rights crib sheet' (which was, however, not mandatory to follow) when informing suspects about their right to a lawyer. The crib sheet was simply worded and included the essential information about the right to free and independent legal advice. Most officers employed a combination of reading from the sheet verbatim, re-phrasing certain parts of it and adding own explanations. ${ }^{109}$

Across all jurisdictions, information about the rights - including the right to a lawyer - was provided differently to suspects who had no prior experience of police custody and to those who were considered 'regulars'. 110 Officers generally took more time to explain the right to legal advice to 'first timers', whilst 'regulars' were often dealt with in a hasty manner, with some information being omitted.

In all jurisdictions, there were indications that officers sometimes let suspects know that if they request a lawyer, they would remain in custody longer. ${ }^{111}$ Often, this was not a conscious attempt to dissuade suspects from taking up legal advice, but almost certainly it had such an effect on some suspects. This is because the suspects' emotional need to be released as soon as possible ${ }^{112}$ may preclude them from reasoning rationally about the necessity of legal advice. Besides, telling suspects that exercising their right to a lawyer will lead to a delay is often misleading, even if the officer genuinely believes that it is accurate. Research carried out in England and Wales has shown that the time spent waiting for a law-

106. Ibid. at $279-80$

107. See above.

108. Blackstock et al., above n. 11 at 232-33.

109. Ibid. at 228.

110. EngSite1Pol3; EngSite1Pol6; EngSite2Pol7; EngSite1Pol11; iEngSite1Pol2; ScotSite1Pol10; ScotSite2Pol25.

111. Blackstock et al., above n. 11 at 274; iEngSite1Pol2; iEngSite1Law1; EngSite1Pol9; iFranSite1Law1; iFranSite1Law7. For the Netherlands, see the examples cited above n. 100.

112. Previous research found that avoiding delay was one of the most common reasons, for which suspects refused legal assistance. L. Skinns, 'Let's get it over with; early finding of the factors affecting detainees' access to custodial legal advice', 19(1) Policing and Society 58 (2009); V. Kemp, " "No Time for Solicitor": Implications for Delays on the Takeup of Legal Advice', 3 Criminal Law Review 184 (2013). yer's arrival did not result in longer periods of police custody. ${ }^{113}$ In the Netherlands, a recent empirical study has shown that the fact that police had to wait for a lawyer to arrive before interrogating a suspect prolonged the time of police custody only unsubstantially, i.e. on average for about 40 minutes, contrary to the officers' perception that the resulting delay was about 2 hours. ${ }^{114}$ Only in England and Wales ${ }^{115}$ did we observe officers asking suspects about the reasons for a waiver of the right to legal advice (where this is also required by PACE). ${ }^{116}$ In the other jurisdictions, by contrast, the officers we observed did not inquire into the reasons for the refusal. Where it was clear that suspects waived the right, falsely believing that doing so would cause a long delay, or that it would send a message to the authorities that they are guilty, often police officers did not correct them in these beliefs. For instance, in one case in Scotland, an officer did not seek to correct the suspect, who had mistakenly believed that waiting for a lawyer would 'take all night' and therefore waived his right to legal assistance. ${ }^{117}$ Such a waiver can hardly be 'informed', as it was clear that the suspect did not understand the implications of exercising the right.

Practices for informing vulnerable suspects about their right to legal advice, depending on the nature of their vulnerability and age, were lacking across all four jurisdictions. Police officers have readily recognised in interviews the challenges of informing vulnerable suspects about their rights and of accepting a waiver of the rights made by vulnerable suspects. ${ }^{118}$ None of the officers, however, mentioned that they received any training on this matter. In the Netherlands, for example, some interviewed officers told us that they developed their own approach to informing children about their rights, for instance, by using a more empathetic tone ${ }^{119}$ and simpler language ( 'lawyer' instead of 'solicitor') ${ }^{120}$ or involving parents in making a decision. ${ }^{121}$ However, despite the appreciation of the special needs of vulnerable suspects expressed in interviews, both in the Dutch and English sites we observed that the information about the right to legal advice was sometimes provided to such suspects in a perfunctory ${ }^{122}$ or hasty ${ }^{123}$ manner.

113. Skinns, ibid. at 64; V. Kemp, N.J. Balmer \& P. Pleasance, 'Whose Time Is It Anyway? Factors Associated with Duration of Police Custody?', 10 Criminal Law Review 736 (2012).

114. W.J. Verhoeven and L. Stevens, Rechtsbijstand bij politieverhoor (2013), at 287, 295

115. EngSite1Pol11; EngSite2Pol7

116. See Section 2.1.1 above

117. Blackstock et al., above n. 11 at 274

118. Ibid. at 243-44

119. iNethTownPol3; iNethCityPol5; iNethCityPol3; iNethTownPol4.

120. iNethCityPol2; iNethCityPol3.

121. iNethSite2Pol1; iNethSite2Pol2.

122. For example, NethSite1Law7 and NethSite1Pol13, where detainees with suspected mental health issues were informed about their rights briefly through a cell window, because the officers feared to provoke an aggressive reaction from them if lengthier explanations were provided.

123. See, e.g., Blackstock et al., above n. 11 at 245-46; EngSite2Pol5. 
4.2 Timely Access to a Lawyer of One's Choice Although the right of timely access to a lawyer and the right of access to a lawyer of one's choice were treated separately in the sections concerning the respective European standards, ${ }^{124}$ it is preferable to address them together when discussing their implementation. That is because, as our research has shown, in practice these two elements are inter-related. Ensuring timely access to a lawyer of one's choice may be a much more challenging task than ensuring timely access to any lawyer. Yet, as it will be argued below, ${ }^{125}$ access to a lawyer whom a suspect knows and trusts is an important precondition of effective legal assistance particularly in the context of police custody. Appropriate measures must be taken not only by the government and the law enforcement authorities but also by the legal profession to effectuate the right of timely access to a lawyer of one's choice in police custody. Relevant legislation is important to ensure that any exceptions to the right of access to one's lawyer are narrowly defined, yet a whole range of practical measures described below are needed to ensure that the right becomes 'practical and effective'.

\subsubsection{Timely Access to a Lawyer of One's Choice: Legislative Framemork}

In all jurisdictions, suspects are entitled to have access to a lawyer in police custody, and in any case - subject to some exceptions - before the first interrogation. In England and Wales and in France, access to a lawyer may be delayed for a limited time ${ }^{126}$ and in limited circumstances. In England and Wales, these include the situations where, for instance, there are grounds to believe that the solicitor will cause an interference with the investigation (e.g. by tampering with evidence), and it is only possible in serious cases. ${ }^{127}$ The circumstances in which these provisions may be applied are further limited by case law. ${ }^{128}$ Likewise, in France, the exception is narrowly drafted, and includes the situations where it is demonstrated in concreto that granting immediate access to a lawyer will interfere with the collection of evidence, completing the investigation or will cause risk to persons. ${ }^{129} \mathrm{~A}$ similar provision, referring to 'exceptional circumstances', exists in Scotland, but it has not (yet) been defined by law when such circumstances may arise. ${ }^{130}$

Related to the issue of derogation from the right to legal advice is the question of whether, and under which circumstances, the police may interrogate a suspect who has not met with a lawyer and has not waived the right

124. See Sections 3.2 and 3.3 above.

125. See in particular Section 4.2 .2 below in respect of the Netherlands.

126. Up to 36 hours in England and Wales in case of 'ordinary offences', and up to 48 hours in case of 'terrorist offences'. In France, to the period of maximum 12 or 48 hours in case of 'ordinary offences', and 72 hours in case of 'organised and terrorist offences'. Blackstock et al., above n. 11 at $78,92$.

127. PACE, Sections $58 \& 58 \mathrm{~A}$

128. Blackstock et al., above n. 11 at 78 .

129. Ibid. at 92 .

130. Ibid. at 128. to legal advice. The Directive provides for this to be only possible in two situations, namely where it is necessary to 'avert serious adverse consequences for the life, liberty or physical integrity of a person'131 or to 'prevent substantial jeopardy to criminal proceedings'. ${ }^{132}$ Only the English law ${ }^{133}$ complies with these exceptions, stating that the police cannot interrogate suspects before they have met a lawyer, subject to the exception mentioned in the paragraph above. ${ }^{134}$ In the Netherlands and in France, by contrast, the police are entitled to commence an interrogation if the lawyer does not arrive within 2 hours from the moment he had been notified. ${ }^{135}$ This is clearly in breach of the Directive ${ }^{136}$ and ECtHR case law. ${ }^{137}$ Even though the Directive provides for a possibility of a (temporary) derogation from the right of access to a lawyer 'where immediate action by the investigation authorities is imperative to prevent substantial jeopardy to criminal proceedings', ${ }^{138}$ this provision may hardly be used to justify a general norm authorising the police to derogate from the right to legal assistance due to the lawyer's late arrival. According to the Directive, derogations from the right of access to a lawyer at the pre-trial stages of the proceedings are possible only in limited, exceptional, circumstances. ${ }^{139}$ They must furthermore be authorised on a case-by-case basis following an examination of the existence of the grounds for such derogation of the kind mentioned in Article 3(6)(b). ${ }^{140}$ Clearly, a blanket authorization to interrogate a suspect if a lawyer fails to meet with the suspect within a certain (arbitrarily defined) time period, without the requirement to assess whether the grounds for derogation from the right of access to a lawyer apply in each given case, does not comply with the aforementioned provisions of the Directive.

In France and in the Netherlands, the 2-hour waiting time before the police are entitled to commence an interrogation translates into a regulation, requiring lawyers to attend police stations within 2 hours. In England and Wales, by contrast, there is no legal requirement for lawyers to attend within a certain time. However, the conditions of the contract, which the government

131. Directive on the right of access to a lawyer, above n. 5, Recital 31

132. Ibid., Recital 32.

133. Note that the Scottish law on this issue is not yet adequately developed.

134. Code of Practice C, para. 6.6.

135. Blackstock et al., above n. 11 at 91, 268.

136. Directive on the right of access to a lawyer, above n. 5, Arts. 3(5) and (6) and 8, Recitals 30-32.

137. See, in particular, Pischchalnikov v. Russia, Directive on the right of access to a lawyer, above n. 50, 79: 'Moreover, the Court is of the opinion that an accused such as the applicant in the present case, who had expressed his desire to participate in investigative steps only through counsel, should not be subject to further interrogation by the authorities until counsel has been made available to him, unless the accused himself initiates further communication, exchanges, or conversations with the police or prosecution.'

138. Directive on the right of access to a lawyer, above n. 5, Art. 3(6)(b). According to Recital 32, 'substantial jeopardy' means the risk of destruction or alteration of 'essential' evidence and the risk of interference with witnesses.

139. Ibid., Art. 3(6). Also see Recitals 30-2, which reflect the exceptional and urgent nature of any derogations from the Directive.

140. Ibid., Art. 8(2) and (3). 
concludes with criminal defence lawyers wishing to provide criminal legal aid services, include a target attendance time of 45 minutes. ${ }^{141}$

In all examined jurisdictions, with the exception of France, legally aided suspects may express a preference for a certain lawyer to assist them in police custody. ${ }^{142}$ However, their choice - if they wish to have free legal assistance - is limited to those lawyers who have signed up for the provision of police station duty services. In England and Wales, where the lawyer named by the suspect cannot attend, officers must ask the suspect if he wishes to consult another solicitor or to proceed without a solicitor, ${ }^{143}$ whilst in the Netherlands there is no such requirement. Thus, the Dutch authorities would be entitled to appoint another lawyer to a legally aided suspect ex officio, if the chosen lawyer is unavailable. ${ }^{144}$

\subsubsection{Timely Access to a Lawyer of One's Choice in Practice}

The arrangements for contacting and appointing lawyers promptly upon detention worked rather efficiently in all studied jurisdictions. This was possible due to the existence of duty lawyer schemes, which ensured that lawyers were contacted immediately, and that there were lawyers available on short notice to provide advice at police stations. Clearly, setting up such a scheme is the only possible way to guarantee the right of timely access to a lawyer in police custody. ${ }^{145}$

Similarly, the time limits set for making contact with suspects were usually met by lawyers - although with a caveat that in England and Wales lawyers have attended their clients immediately before the interrogation, but not at the very outset of detention (as the interrogation normally took place towards the end of custody); and that in Scotland most of legal advice was provided by telephone. ${ }^{146}$

In the Netherlands it transpired from the observations that, as far as duty lawyers were concerned, the 2-hour time limit was usually met. Alternatively, lawyers were able to find a replacement or to negotiate a later attendance time with the police. Likewise, empirical research conducted in parallel with this research project revealed that this time limit did not appear to pose significant problems in practice. ${ }^{147}$ However, sometimes 'duty' lawyers were unable to attend within the 2-hour time limit. In such situations, police officers usually waited

141. Legal Aid Agency, 2010 Standard Crime Contract - Specification, para. 50, 9.52 (c), available at: <www.justice.gov.uk/downloads/egal-aid/ crime-contract-2010/specification-2012-part-b-apr-2012-1-apr-12.pdf> (last visited 18 December 2013).

142. In France, suspects who have opted for a duty lawyer appointed by the state could not choose a certain lawyer.

143. Blackstock et al., above n. 11 at 78.

144. Of course, the suspect would still be entitled to refuse to be assisted by a lawyer altogether.

145. For more detail about the operation of the schemes, see Blackstock et al., above n. 11 at 262-73.

146. See below.

147. Unless the police station was located some distance from the location of the offices of the duty lawyer, or when this was combined with the lawyer's other commitments, such as calls from other police stations and court appointments. until the lawyer arrives and did not proceed with an interrogation. Yet, the possibility that the police would decide to interrogate a suspect without waiting for a lawyer was not excluded. Indeed, one Dutch lawyer reported that it had happened in one of her cases. ${ }^{148}$

In contrast to 'duty' lawyers in the Netherlands, when it concerned 'own' lawyers, i.e. lawyers who were not on duty but were named by suspects, it appears that for many of them attending within 2 hours was problematic. ${ }^{149}$ These lawyers were often engaged elsewhere, i.e. with other clients or in court, and thus they were often unable to attend the police station on short notice. If they were unavailable to attend, these lawyers usually made arrangements with the duty lawyer, or another lawyer, to assist the suspect; or alternatively, police officers requested the duty lawyer to see the suspect. Often, it emerged during the consultation that the suspect's opinion about the change of a lawyer was not asked either by the lawyers ${ }^{150}$ or by the police. ${ }^{151}$ This was true both for privately paying and legally aided suspects. In fact, police officers did not know whether a certain suspect was benefiting from legal aid or paying his lawyer privately. 152

Often, the fact that suspects' consent to the change of a lawyer was not asked provoked their mistrust of the 'imposed' lawyer, which in turn limited the lawyer's ability to give effective advice. For instance, in one case observed in the Netherlands, a suspect of burglary, who was attended by a 'duty' lawyer instead of a preferred lawyer, refused to tell the lawyer about the circumstances of his arrest or his criminal record, or to respond to any other questions posed by the lawyer. As a result, all that the lawyer could achieve in the consultation was to remind the suspect that he should 'keep his mouth shut'. ${ }^{153}$ This example demonstrates that having an opportunity to meet with the lawyer who the suspect knows and trusts is an important pre-requisite for effective legal assistance. In other observed cases, the assistance of the 'duty' lawyer, where the suspect has expressed preference for an 'own' lawyer was less efficient because the 'duty' lawyer did not know about the suspect's medical, family or criminal history

and therefore was unable to properly gauge his advice ${ }^{154}$ and/or identify and act upon any special needs of the suspect. ${ }^{155}$

Our research on the Dutch sites demonstrated that it is challenging to ensure that suspect's choice of a lawyer is

148. NethSite2Law11.

149. During the observations with 'duty' lawyers, researchers often encountered suspects who were re-referred to a 'duty lawyer', because their 'own lawyer' could not timely attend.

150. NethSite1Law2; NethSite1Law9,

151. NethSite1Law11; NethSite1Law15; NethSite2Law12.

152. NethSite1Pol12; NethSite1Law11.

153. NethSite1Law11. The suspect had had previous experience with the criminal justice system, and he knew about the right to remain silent.

154. For example, information about the criminal record is needed for a lawyer to be able to predict how long a suspect may remain in detention.

155. In NethSite1Law5, a duty lawyer was invited to assist a suspect, who had suffered from mental disability, but because he did not know his medical history, he was unable to suggest to the police what kind of protection measures may be needed. 
respected in the context of police detention. Lawyers often have a busy schedule of court sessions and are unable to attend with 2-hour notice, and the police are under pressure - particularly in respect of minor offences - to interrogate quickly in order to reduce the suspect's time in custody. In England and Wales, however, this problem did not surface to the same extent, due to the differences in the organisation of the legal profession. There, lawyers engaged in police station advice were usually part of a criminal defence firm, and clients and cases were shared within this firm. Thus, the client's choice was vested with the particular firm, rather than with an individual lawyer, and as a rule, each law firm had a member of staff available to attend police stations at any time. ${ }^{156}$

The lawyers' professional ideologies and views of their own role was another significant factor in ensuring timely and effective access to a lawyer in police custody. Thus, for example, for Dutch lawyers personal attendance at a police station was a 'norm', and most of them opposed the idea of providing legal advice by telephone (even though advising suspects by phone would have eliminated the need to organise timely attendance at police station). ${ }^{157}$ Many Scottish lawyers, in contrast to their Dutch colleagues, opted for providing advice to suspects detained at police station by telephone, justifying this by the fact that their only role is to advise suspects to remain silent, but most probably doing so to avoid the need to promptly attend suspects in person. ${ }^{158}$ Some Dutch and Scottish lawyers we observed appeared to underappreciate the significance of timely attendance of a client at police station, prioritising their other personal or professional tasks over assisting the client as promptly as possible (e.g. failing to visit a suspect in the evening if he was to be interrogated the following morning). ${ }^{159}$ Other Dutch lawyers have striven to meet with the clients immediately after they were detained, also late in the evening. ${ }^{160}$ The English lawyers, like the Dutch lawyers, considered attendance of suspects in person as a 'norm'; however, they usually visited the suspect just before the interrogation, but not at the very outset of police custody. ${ }^{161}$ This left little room for lawyers to ensure the suspect's welfare and to provide moral support to them throughout the police custody, as the interrogation normally took place in the very end of the custody period.

Furthermore, there were indications that in France, and by some lawyers, albeit a minority in the Netherlands, police station legal advice was seen as a one-off activity,

156. Although many firms employed so-called 'independent agents' to attend police stations during anti-social hours. Blackstock et al., above n. 11 at 263 .

157. Ibid. at 287

158. Ibid. at $288-89$

159. Ibid. at 429 .

160. NethSite1Law15; NethSite2Law10; NethSite2Law5.

161. This was also partly due to the structure of the police station legal aid fees. Lawyers received a fixed fee for police station legal advice, and thus they could not claim additional compensation for several visits of a client while in police custody. See generally Blackstock et al., above n. 11 at $285,429-30$ i.e. there was no expectation that the same lawyer would continue to assist the suspect on the same case. Besides, in France there was no procedure within the duty lawyer scheme run by the local Bar to ensure that the same lawyer would be invited to visit the suspect throughout the police custody and beyond. ${ }^{162}$ This demonstrates the underappreciation of the need for continuity of legal advice by (some members of) the legal profession. In contrast, in England and Wales and in the Netherlands, there was an expectation that the same lawyer (in England and Wales, the same firm) will continue assisting the suspect throughout.

\subsection{Lawyers' Presence and Role at Suspect Interrogation}

The provisions on the right to lawyer's presence and the role of a lawyer during the interrogation of a suspect were among the most debated in the newly adopted Directive. During the negotiations, there was opposition to the idea of a universal right to have a lawyer present or vesting him with anything more than an observatory role during suspect's interrogations. ${ }^{163}$ Therefore, the implementation of the respective provisions of the Directive is likely to be particularly challenging. Below we set out the possible legal and practical obstacles to the implementation of the right to have a lawyer present at the interrogation and the right to effective assistance of a lawyer therein, which may arise in the Member States.

\subsubsection{Regulations on Lamyers' Presence and Their Role during Suspect Interrogation}

The suspect's right to have a lawyer present at interrogation has long been provided for in the law of England and Wales. ${ }^{164}$ In France and Scotland, similar provisions were introduced fairly recently. ${ }^{165} \mathrm{By}$ contrast, in the Netherlands there is no general right of suspects to have their lawyer present in police interrogations. In the Netherlands, juvenile suspects have the right to choose between the presence of a lawyer or a 'trusted person', i.e. a parent or a relative, at their interrogation. No other categories of suspects have the right to have their lawyer attend their questioning. ${ }^{166}$ In our view, Dutch law does not comply with the ECtHR standards in this regard. The ECtHR case law standards state unequivocally that suspects must have the right to have their lawyer present at their interrogations. ${ }^{167}$ Likewise, the Directive on the right of access to a lawyer provides for the right of

162. Ibid. at 305-6.

163. See note by Belgium, France, Ireland, the Netherlands and the United Kingdom dated 21 September 2011 to the Council of the EU (2001/0154 (COD), No. 14495/11 expressing concerns about the proposed Directive.

164. Since the entry into force of PACE in 1986. PACE, Section 58; PACE Code of Practice C, para. 6.8.

165. For the relevant references to legislation and case law, see Blackstock et al., above n. 11 at $97,128$.

166. For the relevant references to legislation and case law, see ibid. at 109.

167. The most recent case, where the ECtHR addresses specifically the right to have a lawyer present during the interrogations, is Navone and others v. Monaco, above at 4, 72-85. 
every suspect and accused person to 'have their lawyer present and participate effectively when questioned.'168

The extent to which the lawyer's role during the interrogation is regulated by law, and the scope of that role, differs greatly per jurisdiction. The most detailed regulation is to be found in England and Wales:

'The solicitor's only role in the police station is to protect and advance the legal rights of their client... The solicitor may intervene [in an interrogation] in order to seek clarification, challenge an improper question to their client or the manner in which it is put, advise the client not to reply to particular questions, or if they wish to give their client further legal advice. 169

170 This decision can only be made by a senior officer, and if the decision is made to exclude the lawyer, the suspect must be given the opportunity to consult another solicitor. However, in practice lawyers are removed from interrogations very rarely, and only when their behaviour becomes seriously disruptive (e.g. shouting or repeatedly responding to questions for his client).

France was the other country where the lawyer's role at interrogation was defined by statute, however in a much more limited way than in England and Wales. There, lawyers are not supposed to intervene during the interrogation, except for at the end of the interrogation to ask questions to the suspect or to make remarks. ${ }^{171}$ If lawyers do not adhere to these provisions, police officers are entitled to stop the interrogation and request for another lawyer to be appointed. ${ }^{172}$

In contrast to England and Wales and France, in the Netherlands and Scotland there is no statutory definition of the role of a lawyer during interrogation. Some provisions are to be derived from the various instructions adopted by the prosecutor's office or the police; ${ }^{173}$ however, it is unclear whether they are binding on lawyers. In Scotland, these documents envisage a broad role for a lawyer during interrogation, although not as broad as in England and Wales. Namely, lawyers may advise their clients, including advice not to respond to questions, seek to ensure that clients understand questions and object to oppressive questioning or improper behaviour by the police. ${ }^{174}$ In the Netherlands, lawyers may only intervene to ensure that the suspect understands the question posed by the police, to ensure that no undue pressure is applied on him and to propose corrections to the interrogation record. If lawyers fail to abide by these rules, they can be excluded from the interrogation. ${ }^{175}$

168. Directive on the right of access to a lawyer, above n. 5, Art. 3(3)(b).

169. PACE Code of Practice C, Note for Guidance 6D

170. PACE Code of Practice C, paras. 6.9-6.11.

171. Art. 63-4-3 French CCP.

172. Ibid

173. For references to the relevant acts, see Blackstock et al., above n. 11 at $115-16,397$ and 400 .

174. Ibid. at $400-1$.

175. Aanwijzing rechtsbijstand politieverhoor 15 februari 2010, Stcrt. 2010, 4003.
Moreover, in France and in the Netherlands the national (criminal) Bar associations adopted alternative sets of guidelines, which encourage their members to take a more active stance during the suspect interrogation than provided for in the law or in the internal law enforcement regulations. ${ }^{176}$ However, it appears that these guidelines remain largely aspirational until the Directive is implemented in national law. ${ }^{177}$

\subsubsection{Lamyers' Presence and Role at Interrogations in Practice}

Significant differences were observed as to whether lawyers attended the interrogations of suspects by the police during police custody. In England and Wales and in France, there was a general expectation that a lawyer would attend all custodial interrogations of a suspect, and the lawyers we observed did in fact do so. ${ }^{178} \mathrm{By}$ contrast, Scottish lawyers usually did not attend interrogations, because they preferred to deal with the entire police station legal advice by telephone. ${ }^{179}$ Dutch lawyers appeared to attend suspect interrogations rarely, even when they were entitled to do so (i.e. in the case of juveniles). ${ }^{180}$

The roles that lawyers exercised during the interrogation, and the degree to which they intervened ${ }^{181}$ at interrogations, varied even more between the four jurisdictions. Lawyers in England and Wales were generally more interventionist than the lawyers in the other three countries, which is to be explained by a combination of reasons, such as: clear and detailed regulations as to when lawyers may intervene and for what purpose; existence of an accreditation process, which aims to test lawyers' skills in intervening; and greater acceptance by the police of lawyer's presence and their role at the interrogation than in the other three jurisdictions. ${ }^{182}$

In Inside Police Custody, we identified a range of factors, other than the existence of relevant legislation, which determined whether lawyers were present at interrogations of their clients, and whether they assumed an active role during such interrogations. ${ }^{183}$ These were the factors related to the payment for police station legal

176. Ibid. at 405 .

177. The Dutch government has introduced legislative proposals to implement the Directive on the right of access to a lawyer in February 2014 (i.e. in the period after the completion of our research). These proposals provide for the right of access to a lawyer during interrogations of all suspects by police, and give more rights to lawyers to intervene during the interrogation. See Wetsvoorstel implementatie richtlijn Recht op toegang raadsman, available at: <www.rijksoverheid.nl/documenten-enpublicaties/kamerstukken/2014/02/13/westvoorstel-implementatierichtlijn-recht-op-toegang-raadsman.html> (last visited 10 June 2014); Besluit inrichting en orde politieverhoor, available at: <www. rijksoverheid.nl/documenten-en-publicaties/besluiten/2014/02/13/besluit -inrichting-en-orde-politieverhoor.html> (last visited 10 June 2014).

178. Ibid. at 385 .

179. Ibid. at 386-87.

180. In our sample, from seventeen observed interrogations involving a juvenile, lawyers were present only in eight of them. Ibid. at 386. For similar findings, see Verhoeven and Stevens, above n. 114 at 266-68.

181. By "intervention" at the interrogation we mean a verbal remark or question, aimed to fulfill one of the purposes set out in the general description of the lawyer's role as described above in Section 3.3.1.

182. Blackstock et al., above n. 11 at 396-97.

183. Ibid. at 387-408 
advice, organisational factors related to the delivery of legal advice as well as the planning of police interrogations, the attitudes of the police to the lawyer's presence and role at the interrogation and the respective lawyers' professional attitudes. These factors will be briefly addressed below.

One important factor that influenced the attendance of interrogations was the organisation of the duty lawyer schemes and the structure of remuneration for legal advice. Thus, for instance, in England and Wales and in France there were financial incentives for the lawyers to attend suspect interrogations, ${ }^{184}$ because attendance of interrogation was paid at a significantly higher rate than a prior consultation with the client. In the Netherlands, by contrast, the payment structure discouraged attendance of interrogations, because lawyers were paid significantly less pro rata for the time spent in attending an interrogation than for a pre-interrogation consultation. ${ }^{185}$ However, the financial arrangements were not the only, or even a determinative, factor. The way in which police station legal assistance schemes were organised also had an impact on lawyers' attendance. Thus, in England and Wales and in France, lawyers were expected to attend interrogations if they accepted appointment for police station legal advice (for instance, in France they had to report on such attendance to the Bar coordinator in order to collect a fee), and if a lawyer knew that he would have no time to attend the interrogation, he was expected to refuse providing assistance to the client altogether. In the Netherlands, by contrast, duty lawyers appeared to prefer to take up most requests for legal advice personally, and generally did not re-refer the client to another lawyer if they did not have time to attend the interrogation. ${ }^{186}$

Another factor that influenced whether lawyers attended interrogations was the way in which the police approached the planning of interrogations. Generally, in none of the four jurisdictions with the exception of England and Wales, was there an expectation that the police would adjust the timing of the interrogation to the lawyer's availability. ${ }^{187}$ Furthermore, in one of the French sites, there was not even a standing practice that the police would give lawyers a margin of 1 hour to organise attendance of suspect interrogation (where this was a second or a third interrogation of a suspect in custody). ${ }^{188}$

Lawyers' own attitudes to attendance and their understanding of their role during the interrogation were other factors that determined attendance. As our study revealed, lawyers in different jurisdictions gave different, and sometimes contradictory, justifications as

184. Ibid. at 388 .

185. At the time of the fieldwork, a 30-minute consultation was paid at EUR 85-255, and attendance of interrogation was paid at a fee of EUR 113-339 notwithstanding its duration (which could be several hours). See ibid. at 117-18, 388.

186. Ibid. at 389.

187. In England and Wales, regulations provide that the police should normally wait for the lawyer's arrival before commencing an interrogation. PACE Code of Practice C, para. 6.8, Note for Guidance 6A.

188. Blackstock et al., above n. 11 at 391 . to why their attendance at interrogations was unnecessary. ${ }^{189}$ For instance, most Scottish lawyers believed that they did not have to attend if they had advised clients to remain silent at the interrogation. By contrast, one Dutch lawyer said that he thought it was unnecessary to attend where a suspect was going to respond to questions at the interrogation. ${ }^{190}$

In the Netherlands, some lawyers told us that they believed it was important to attend every suspect interrogation, however minor the offence that their client was suspected of. Others said that they would attend interrogation selectively, depending on the seriousness of the case or the clients' wishes. ${ }^{191}$ Furthermore, lawyers' attitudes to attending interrogations may have played a role in their decision whether or not to attend. ${ }^{192}$ Many of the Dutch lawyers, for example, expressed rather negative attitudes to being present at interrogations. The passivity of their role at the interrogation, absence of prior knowledge about the evidence (other than from the suspect) and the length and slow pace of interrogations, coupled with low remuneration, all contributed to the fact that many Dutch lawyers perceived the attendance of interrogations as not the most interesting or challenging part of their job. ${ }^{193}$ In Scotland, some of the interviewed lawyers had expressed little interest in attending interrogations, because 'everything was tape-recorded anyway'. ${ }^{94}$

As far as the lawyers' role at interrogations was concerned, the main factor that influenced the way it was shaped in the different jurisdictions, besides the existence of clear and detailed regulations that defined the lawyers' role, were the professional attitudes of the police towards lawyers. There was a stark difference in the way that lawyers who attended interrogations were perceived and treated by the police in England and Wales (a jurisdiction which has significantly longer experience with police station legal advice) and the other three jurisdictions. In the Netherlands, and to some extent in France, police officers have expressed generally neutral or negative attitudes towards the presence of a lawyer at interrogations, however, most of them have shown strong opposition to the idea that lawyers should be able to play any active role in the interrogation. ${ }^{195}$

Different strategies were observed aimed at diminishing the effect of the lawyer's presence on the course of the interrogation. Thus, for example, in the Netherlands lawyers were sometimes required to go to the adjacent recording room, if the interrogation was audiovisually recorded, which prevented them from intervening in any way (as well as from seeing clearly what is happening in the interrogation room) ${ }^{196}$ If lawyers were pres-

189. Ibid. at 392.

190. Ibid.

191. Ibid.

192. Ibid. at 392-94

193. Ibid. at 393.

194. This view is, however, not accurate, which also reflects on how little (some) Scottish lawyers are familiar with the police detention procedure. Ibid. at 393

195. Ibid. at 402-3.

196. Ibid. 
ent in the room, they were sometimes placed behind the suspect or in the corner, to prevent the possibility of eye contact between the lawyer and the suspect, and to symbolically remove the lawyer from the interrogation table. ${ }^{197}$ Another technique, used rather commonly, was to reprimand a lawyer for 'obstructionist' behaviour and to threaten to remove a lawyer from an interrogation room. ${ }^{198}$ Similarly, in France lawyers appeared to be threatened with the so-called 'incident report', i.e. a request made by the police to the Bar to appoint another lawyer instead of the one who aims to 'obstruct' an interrogation.

Where the general attitude of the police towards lawyers' interventions is hostile, it is difficult to expect that an 'interventionist' culture of legal assistance during suspect interrogations would emerge without a concerted action on behalf of the legal profession. Such action should be aimed at defining clearly the lawyer's role at interrogations and at training lawyers to intervene appropriately and assertively. For example, the findings of our study analysed together with the findings of earlier research suggest that in England and Wales lawyers' participation in interrogations, and their interventions have significantly increased after the Law Society introduced police station legal advice training and accreditation schemes, which inter alia required lawyers to react in situations when an intervention was called for, and to respond to them appropriately. ${ }^{199}$

\section{Conclusions}

The Directive on the right of access to a lawyer is an important step on the path towards the development of a fair and effective system of protection of suspects' procedural rights in the EU. However, it is only the first step. To ensure that the Directive applies directly in a police station located in the Scottish Highlands or in the heart of Amsterdam, further measures will have to be taken by the Member States, national Bars and legal professions. Thus, transposition of the Directive into national laws of the Member States will require the development of complex nationwide programmes, accompanied by a range of organisational and policy measures and training of relevant criminal justice personnel. The European Union institutions may assist the Member States in this respect by providing guidance and financial or institutional support.

Based on the analysis of the regulations and practice of the implementation of the right to legal assistance in the four European jurisdictions, we propose below a range of measures which, in our view, should accompany the adoption of legislation implementing the Directive. ${ }^{200}$ These measures could also be incorporated in the review

197. Ibid.

198. Ibid. at 404.

199. Ibid. at 405.

200. This list builds upon, and develops the list of measures proposed in Ibid. at 451-57. procedure by the European Commission which has to be presented to the European Parliament and to the Council 1 year after the relevant transposition date to assess compliance of the Member States with the Directive.

\subsection{Information on the Right to Legal Advice and Waiver}

- Detailed procedures on informing suspects about the right to legal advice should be developed, which should avoid using prescriptive language, but define the content and the manner in which the information should be provided (e.g. both orally and in writing, in a clear and understandable manner, with appropriate detail, and avoiding formal or officious language. Information on the right to legal advice should be provided by a police officer who is independent from the investigation.

- Officers should be trained to deliver the information about the right to legal assistance in a neutral manner and to encourage suspects to take up this right in appropriate circumstances (e.g. serious cases, vulnerable suspects). The use of tactics aimed at dissuading suspects from the exercise of the right to legal advice should be prohibited. Caution should be exercised when informing suspects that taking up the right to a lawyer will cause delay, as it is likely to dissuade them from obtaining legal advice. Officers should be trained to avoid shortcuts when informing suspects about their rights, when it concerns suspects who had previous experiences of police custody.

- Detailed regulations should be developed on the conditions for a waiver of the right to legal assistance, and the procedure to ascertain whether the waiver was valid (i.e. informed and voluntary). These regulations should include the obligation to ask for reasons for the waiver and to record these reasons, as well as to react appropriately, should it appear that the waiver is ill-informed.

- Special procedures should be developed to inform vulnerable suspects about the right to legal advice, depending on the nature of their vulnerability and age. Other mechanisms to facilitate the provision of information to such suspects should be considered, such as the institution of an 'appropriate adult'. In addition, consideration should be given to developing regulations according to which some categories of suspects, e.g. very young children or particularly vulnerable suspects, should not be able to waive their right to a lawyer.

\subsection{Timely Access to a Lawyer of One's Choice}

- Legislation aimed at implementing the Directive should include a provision prohibiting the commencement of interrogation before the suspect had an opportunity to exercise the right. Any exceptions to this provision should be drawn narrowly in line with the Directive. Failure of the lawyer to arrive at the police station within a certain time should not constitute a legitimate exception to this provision. 
- Duty lawyer schemes should be introduced to ensure that lawyers are available to provide advice at police stations on short notice. There should also be a corresponding obligation of the police to engage the duty lawyer scheme in a timely fashion and to facilitate effective access to a lawyer.

- Detailed procedures should be developed to ensure that suspects' wishes to be advised by a particular lawyer or by a particular law firm are taken into account. Police officers should be trained to recognise the importance of assistance by a lawyer of one's choice and continuity of legal advice. In any case, suspects who pay for a lawyer privately should be able to benefit from the assistance of their own lawyer.

- Measures should be taken to encourage timely attendance of police stations by lawyers, for instance, by incorporating relevant attendance time targets as conditions for participation in the duty lawyer scheme. Lawyers should be encouraged to organise their practice in such a way as to ensure that there is staff available to attend police stations at any time, as well as to guarantee the continuity of legal advice.

- Lawyers should be trained to recognise the importance of personal attendance as soon as possible after the moment of detention, and of continuity of legal assistance.

\subsection{Presence of Lawyers at the Interrogation and} Their Role

- Measures should be taken to stimulate lawyers' attendance of suspect interrogations, such as developing appropriate fee structures, as well as other organisational measures, e.g. requiring attendance of interrogations as a condition for participation in the duty lawyer scheme or for receiving a police station advice fee.

- Lawyers should be trained to understand the importance of attending interrogations, even in seemingly trivial matters. Measures should be taken to encourage the development of such a defence culture, where attendance at interrogations is considered an indispensable element of the lawyer's role in police custody.

- Clear and unequivocal regulations of the lawyer's role during interrogation should be developed. These regulations must contain provisions concerning when it is appropriate for lawyers to intervene and for which purpose and what means of intervening should be available to a lawyer. The regulation should also include provisions on where it is appropriate for an officer to exclude the lawyer from the interview, which should be narrowly drawn.

- Regulations should be developed prohibiting officers from engaging in certain strategies aimed at diminishing the effect of lawyers' presence at interrogations. Officers should be trained to recognise the importance of an active lawyer's role during interrogations.
- Lawyers should be trained to assume an active role during suspect interrogations, and in particular to recognise the moments when it is appropriate to intervene and to respond appropriately to the strategies aimed to diminish their impact during interrogations. 